\title{
Preplant Moisture Content and Compaction of Peatwool using Two Irrigation Techniques on Potted Chrysanthemums
}

\author{
Theo J. Blom ${ }^{1}$ and Brian D. Piott ${ }^{2}$ \\ Horticultural Research Institute of Ontario, Vineland Station, Ont. LOR 2EO, Canada
}

Additional index words. container capacity, Chrysanthemum $\times$ monfolium, Dendranthema $\times$ grandiflorum, drainable pore space, porosity, shrinkage, subirrigation, top irrigation

\begin{abstract}
High-volume top irrigation (Chapin) was compared to subirrigation (ebb and flow) using 15-cm-diameter (1.56 liter) pot-grown chrysanthemums [Dendranthema xgrandiflorum (Ramat.) Kitamura] with peatwool (50 peatmoss : 50 granulated rockwool) as the growing substrate. Preplant moisture contents $(25 \%, \mathbf{1 2 5 \%}$, and $250 \%$, gravimetric) and compaction $\left(0,20\right.$, and $\left.50 \mathrm{~g} \cdot \mathrm{cm}^{-2}\right)$ of the peatwool were also studied. Shrinkage of growing substrate was large ( $>309$ '6 of pot volume) when peatwool in the pots was not compacted. Compaction reduced shrinkage and produced plants with larger leaves, more fresh weight, and longer stems than without preplant compaction. Drainable pore space, container capacity, and total porosity was not affected by compaction. The higher preplant moisture contents increased drainable pore space but had no effect on plant growth. Chapin-irrigated plants had significantly more fresh weight $(+24 \%)$ at the pea-size bud stage than plants grown in the ebb-and-flow system. The difference in growth was similar at flowering but significant only at $\boldsymbol{P}=0.08$. Soluble salts concentration in the peatwool and foliar nutrient contents differed at flowering for the two irrigation systems.
\end{abstract}

PeatWool blends have shown potential as potting media (Lee et al., 1987) due to large pore space, water-holding capacity (Fonteno and Nelson, 1990), and excellent rewetting characteristics (Blom and Piott, 1989). The handling and preparation procedures of soilless substrate have pronounced effects on pore size distribution and the water : air ratio in a container (Milks et al., 1989a). Compaction and shrinkage of substrate appear to be a problem with commercial peatwool $(50 \%$ peatmoss and $50 \%$ rockwool).

Subirrigation, a good alternative to top irrigation (high- or low-volume drip), reduces labor and contamination of ground water by recirculating the nutrient solution. No difference in growth (leaf size, fresh weight, or height) was found between subirrigation and low-volume drip (2 liters $\left.\cdot \mathrm{h}^{-1}\right)$ systems with chrysanthemums and poinsettias (Euphorbia pulcherrima Wind. ex K1. ) (Blom and Piott, 1990). Our previous informal observations indicated that there were differences in plant growth between subirrigation and high-volume drip (Chapin) system. The objective of this study was to determine the effects of suband top irrigation and preplant handling of peatwool on performance of potted chrysanthemums.

\section{Materials and Methods}

\section{Substrate preparation}

The premixed commercial substrate was granulated peatwool (Pargro brand) consisting of 50\% sphagnum peat and $50 \%$ nonbonded, medium-grade rockwool amended with limestone and fertilizers (Partek North-America, Peachtree City, Ga.). The medium had a $\mathrm{pH}$ of 5.6 and an electrical conductivity (EC) of

Received for publication 3 Apr. 1991. Accepted for publication 17 Oct. 1991 We acknowledge Partek North-America, Denver, for financial assistance and Aldershot Greenhouses, Burlington, Ont., for the donation of cuttings. We thank Calvin Chong and Robert Cline for their critical review of the manuscript. The cost of publishing this paper was defrayed in part by the payment of page charges. Under postal regulations, this paper therefore must be hereby marked advertisement solely to indicate this fact.

${ }^{1}$ Research Scientist.

${ }^{2}$ Research Technician.
$0.80 \mathrm{mS} \cdot \mathrm{cm}^{-1}$ (SME-method). Azalea pots $(15 \mathrm{~cm}$ in diameter, 1.56 liters) were heaped with peatwool of three gravimetric (100 $\times$ weight of moisture/dry weight of substrate) moisture contents: $25 \%$ (MC-25), $125 \%$ (MC-125), and 250\% (MC-250). MC-125 was the moisture level in the commercially available Pargro, while MC-250 was considered the upper moisture limit for use in a potting machine without risk of clogging. MC-25 was obtained by air-drying the substrate on a sheet of plastic in an empty greenhouse. Substrates at each moisture content were compacted to three pressure levels: $0 \mathrm{~g} \cdot \mathrm{cm}^{-2}(\mathrm{C}-0), 20 \mathrm{~g} \cdot \mathrm{cm}^{-2}$ (C-20), or $\left.50 \mathrm{~g} \cdot \mathrm{cm}^{-2} \mathrm{C}-50\right)$. In noncompacted pots, the heaped substrate was scraped off at the rim of the pot. Compaction was achieved by placing a flat circular $(13 \mathrm{~cm}$ in diameter) disk on top of the heaped medium for 2 to $3 \mathrm{sec}$ with added weights of 2.6 (C-20) or $6.5 \mathrm{~kg}$ (C-50). Following compaction, the pots were filled with loose medium to the rim.

After hand-watering the pots, drainable pore space, container capacity, and total porosity were determined for five pots of each of the nine treatments by the method of Joiner and Conover (1965). Saturation of the pots was obtained by immersing the pots slowly in a water bath until the surface of the substrate glistened. Pots were then removed quickly from the water bath and net weight of substrate was determined. Container capacity was determined after allowing the pots to drain for $24 \mathrm{~h}$. Shrinkage of the peatwool was determined as follows: A piece of cellophane was placed on the surface of the medium, draped over the edge of the pot, and water was added to fill the pot to the rim. Percent shrinkage was based on the weight of water added. Substrate was air-dried at 70C to constant weight. These physical characteristics were also determined at flowering.

\section{Plant culture}

On 29 Mar. and 5 June 1990, four unrooted 'Yellow Favor' chrysanthemum cuttings were planted in pots for all nine peatwool treatments. Cuttings were rooted under polyethylene film for 14 days and grown in a $200-\mathrm{m}^{2}$, double acrylic greenhouse

Abbreviation: EC, electrical conductivity; QI, quality index. 
at a constant $18 \mathrm{C}$ for the duration of the experiments. The growing schedules are shown in Table 1.

Plants were spaced at $30 \times 40 \mathrm{~cm}$ and fertigated by top irrigation (Chapin) or subirrigation (ebb and flow; Dansk Gartneri Teknik A/S, Brandby Strand, Denmark). The high-volume Chapin system (emitters, 25 to 30 liters $\cdot \mathrm{h}^{-1}$, delivered $280 \mathrm{ml} /$ watering. The ebb-and-flow plants were in contact for 30 to 40 min with the irrigation solution, which was recirculated from a 600-liter tank. The irrigation frequency was the same for both systems (one to two times per day). Nutrient levels for both systems were: 200, 85, 165, 40, and $10 \mathrm{ppm}$ of N, P, K, Ca, and $\mathrm{Mg}$, respectively, using 20N-8.7P-16.6K (Plant Products, Bramalea, Ont., Canada) and an EC of $1.4 \mathrm{mS} \cdot \mathrm{cm}^{-1}$. Pots without plants were similarly fertigated throughout the course of each crop.

\section{Sampling}

Shoot length, leaf surface area, and fresh and dry weights of plants were determined at the peabud (early) and at the flowering (end) stage. EC and $\mathrm{pH}$ were also determined at these times using the pour-through method (Wright, 1986; Yeager et al., 1983) with 60 to $70 \mathrm{ml}$ of extractant. The youngest, fully expanded leaves were sampled at flowering and dried at $70 \mathrm{C}$ for 2 weeks, ground, and passed through a 40-mesh screen (3.1$\mathrm{mm}^{2}$ openings) and analyzed for total $\mathrm{N}$ by the Kjeldahl method; $\mathrm{K}, \mathrm{Ca}, \mathrm{Mg}, \mathrm{Fe}, \mathrm{Mn}$, and $\mathrm{Zn}$ by flame emission or. atomic absorption spectrophotometry. Leaf samples were collected for the second planting only. One single pot constituted the experimental unit for the plant traits, the chemical measurements, and the foliar analysis.

\section{Design of experiment}

Each experiment was a split-split block design with irrigation (2) and block (2) as the main components. Moisture content and medium compaction represented the sub- and sub-subplots, respectively. There were five pots per experimental unit. At planting, each block consisted of 180 pots, 90 pots with and 90 without plants. For the analysis of variance (ANOVA), the two blocks for each planting date were averaged and "block" was replaced by "planting date" as the random factor since there was no planting date $\times$ treatment interaction.

\section{Results and Discussion}

\section{Plant growth}

The plants grown with the Chapin system showed a significantly larger (24\%) leaf surface area than those grown with ebband-flow system, as well as increased (24\%) plant fresh weight at the early (peabud) stage (Table 2). These trends were similar at flowering (24\% and $30 \%$, respectively) but statistically dif-

Table 1. Schedule for the two planting dates, 1990.

\begin{tabular}{lcr}
\hline \hline Procedure & Planting 1 & Planting 2 \\
\hline Filling pots & $29 \mathrm{Mar}$. & 5 June \\
Planting cuttings & $30 \mathrm{Mar}$. & 6 June \\
Start of short days & $20 \mathrm{Apr}$. & $25 \mathrm{June}$ \\
Pinching & $23 \mathrm{Apr}$. & $29 \mathrm{June}$ \\
Start of irrigation treatments & $25 \mathrm{Apr}$. & $1 \mathrm{July}$ \\
First sampling (early) & $17 \mathrm{May}$ & $24 \mathrm{July}$ \\
Disbudding & $28 \mathrm{May}$ & $2 \mathrm{Aug}$. \\
Final sampling (flowering) & 27 June & $22 \mathrm{Aug}$. \\
\hline
\end{tabular}

ferent only at $P=0.08$. Plants grown with the Chapin system could be disbudded 2 days earlier than the others. One reason for the difference in plant growth could be that pots in the ebb and flow were drier than the Chapin-watered pots. Sampling with the first planting indicated that the ebb-and-flow pots were wetter before watering (+51 g/pot), while, after watering, the pot weight (excluding plant) was the same for both irrigation systems. This would mean that water uptake by subirrigated plants was less. The ebb-and-flow system produced plants with a higher quality index (QI) at flowering, indicating that less water was absorbed per gram of dry matter than with the Chapin system. The preplant MC of the substrate did not affect any of the plant characteristics. Compaction of the substrate resulted in a larger plant fresh weight $(+9 \%)$, but a lower QI at the early stage compared to no compaction. At flowering, compaction resulted in increased stem length, leaf size $(+7 \%)$, fresh weight (and dry weight) $(+7 \%)$, and number of flowers $(+11 \%)$, while it did not affect QI. No difference was observed between C-20 and C-50 for any of the plant traits. There were no interactions between the irrigation and any of the preplant treatments.

\section{Physical aspects}

The physical characteristics of the peatwool were the same before planting and at flowering when no plants were grown in the substrate. Only data at flowering are therefore given (Table $3)$. Shrinkage $(20 \%)$ of the substrate had taken place with the first watering by hand before planting. Subsequent irrigations $(50 \times)$ did not affect the physical characteristics and were independent of irrigation system. However, moisture content and compaction did affect physical characteristics. A high moisture content of the substrate at filling increased the drainable pore space while it reduced the container capacity. This result implies that more drainable macropores were created when the pots were filled with a wet substrate, but that the number of micropores was reduced. These findings are consistent with those of Milks et al. (1989b), who used 1 peat : 1 vermiculite substrate. The preplant moisture content did not affect the amount of substrate required to fill a pot, shrinkage, or total pore space. Compaction had a highly significant effect on shrinkage. The substrate volume decreased by $33 \%$ without compaction (C-0) compared to $13.4 \%$ for the two combined levels of compaction (C-20 and C-50), when no plants were present. The increased amounts of substrate required were $32 \%$ for C-20 and $44 \%$ for C-50, compared to $\mathrm{C}-0$. The combined effect of reduced shrinkage and increased amounts of the peatwool required due to compaction resulted in a bulk density of $0.110,0.115$, and $0.118 \mathrm{~g} \cdot \mathrm{cm}^{-}{ }^{3}$ for C-0, C-20, and C-50, respectively. Drainable pore space, container capacity, or total pore space were not affected by compaction. The lack of significance of the level of compaction (C-20 vs. C-50) may be caused by the method of compaction (pressure applied at top surface) as well as the conical shape of a pot.

In pots with plants, the volume of the substrate increased (more dry matter and less shrinkage), drainable pore space and total porosity decreased, and container capacity increased between initiation and termination of the tests. The greatest effect of the root system was on drainable pore space $(-10 \%$ absolute), while the container capacity was increased by $4 \%$ (absolute). The resulting total pore space was therefore reduced by $6.6 \%$ (absolute). If the dry weight increase of the peatwool (12.6 g dry weight) was due to the roots developing in the substrate and the fresh : dry weight ratio is assumed to be 10 , 
Table 2. Plant characteristics measured early (4 weeks after start of short days) and late (at flowering) of potted chrysanthemums ('Yellow Favor') grown in 1.56-liter azalea pots with peatwool at three moisture contents and three compaction levels at preplanting. Plants were watered with subirrigation (ebb and flow) or high-volume drip irrigation (Chapin). The numbers presented are averages of two planting dates.

\begin{tabular}{|c|c|c|c|c|c|c|c|c|c|c|c|}
\hline \multirow[b]{2}{*}{ Treatment } & & \multicolumn{2}{|c|}{$\begin{array}{l}\text { Shoot length }{ }^{\mathrm{z}} \\
\quad(\mathrm{cm})\end{array}$} & \multicolumn{2}{|c|}{$\begin{array}{l}\text { Leaf surface } \\
\text { area }\left(\mathrm{cm}^{2}\right) \\
\end{array}$} & \multicolumn{2}{|c|}{ Fresh wt (g) } & \multicolumn{2}{|c|}{$\mathrm{QI}^{\mathrm{z}}(\%)$} & \multicolumn{2}{|c|}{$\begin{array}{c}\text { Flowers/pot } \\
\text { (no.) }\end{array}$} \\
\hline & & Early & Late & Early & Late & Early & Late & Early & Late & Early & Late \\
\hline \multicolumn{12}{|l|}{ Irrigation } \\
\hline Ebb and flow & & 14.2 & 30.4 & 1340 & 3210 & 128 & 384 & 9.5 & 12.5 & --- & 14.5 \\
\hline Chapin & & 15.3 & 29.4 & 1660 & 3840 & 159 & 499 & 9.2 & 10.5 & -- & 15.1 \\
\hline Significance & & NS & NS & $*$ & NS & $*$ & NS & NS & $*$ & --- & NS \\
\hline \multicolumn{12}{|l|}{ Moisture content $(\%)^{\mathrm{y}}$} \\
\hline 25 & $\because$ & 15.0 & 30.3 & 1530 & 3720 & 143 & 456 & 9.4 & 11.4 & $\cdots$ & 14.5 \\
\hline 125 & & 15.1 & 29.6 & 1580 & 3400 & 146 & 429 & 9.4 & 11.6 & --- & 14.9 \\
\hline 250 & & 14.2 & 29.7 & 1410 & 3450 & 140 & 439 & 9.3 & 11.5 & --- & 15.0 \\
\hline Significance & & NS & NS & NS & NS & NS & NS & NS & NS & --- & NS \\
\hline \multicolumn{12}{|l|}{ Compaction (comp.) $\left(\mathrm{g} \cdot \mathrm{cm}^{-2}\right)$} \\
\hline 0 (control) & & 14.7 & 29.4 & 1470 & 3360 & 135 & 404 & 9.5 & 11.4 & -.- & 13.9 \\
\hline 20 & & 14.8 & 30.1 & $153)$ & 3620 & 148 & 458 & 9.3 & 11.5 & --- & 15.3 \\
\hline 50 & & 14.8 & 30.0 & 1500 & 3590 & 146 & 461 & 9.3 & 11.6 & --- & 15.2 \\
\hline \multicolumn{12}{|l|}{ Significance (contrast) } \\
\hline No comp. vs. comp. & & NS & $*$ & NS & $* *$ & $* * *$ & $* * *$ & $*$ & NS & --- & $* *$ \\
\hline $20 \mathrm{~g} \cdot \mathrm{cm}^{-2}$ vs. $50 \mathrm{~g} \cdot \mathrm{cm}^{-2}$ & & NS & NS & NS & NS & NS & NS & NS & NS & --- & NS \\
\hline
\end{tabular}

${ }^{2}$ Shoot length is average of the two top shoots per cutting. Leaf surface area is total area of eight top shoots combined (four cuttings and two top shoots). QI $=100 \times \mathrm{dry}$ weight/fresh weight of plant.

${ }^{y}$ Gravimetric (gram of water/gram of dry weight of peatwool) $\times 100 \%$.

NS,*,**,***Nonsignificant or significant at $P=0.05,0.005$, or 0.0005 , respectively. No interaction between the three main effects.

Table 3. Physical characteristics of peatwool $(50: 50, \mathrm{v} / \mathrm{v})$ with $(+)$ or without $(-)$ chrysanthemum plants in 1.56 -liter azalea pots and filled at three moisture contents and three compaction levels ${ }^{z}$ at preplanting. Plants were watered with subirrigation (ebb and flow) or high-volume drip irrigation (Chapin). The numbers are averages of two planting dates.

\begin{tabular}{|c|c|c|c|c|c|c|c|c|c|c|}
\hline \multirow[b]{2}{*}{ Treatment } & \multicolumn{2}{|c|}{ Shrinkagey $(\%)$} & \multicolumn{2}{|c|}{$\begin{array}{c}\text { Drainable } \\
\text { pore } \text { space }^{y}(\%)\end{array}$} & \multicolumn{2}{|c|}{$\begin{array}{c}\text { Container } \\
\text { capacity }(\%)\end{array}$} & \multicolumn{2}{|c|}{$\begin{array}{c}\text { Total porosity } \\
(\%)\end{array}$} & \multicolumn{2}{|c|}{ Dry wt/pot (g) } \\
\hline & -Plant & + Plant & - Plant & + Plant & - Plant & + Plant & -Plant & + Plant & -Plant & + Plant \\
\hline \multicolumn{11}{|l|}{ Irrigation } \\
\hline Ebb and flow & 19.4 & 16.8 & 21.0 & 11.7 & 73.0 & 75.5 & 93.9 & 87.3 & 143 & 158 \\
\hline Chapin & 20.6 & 17.3 & 17.4 & 5.9 & 75.0 & 79.9 & 92.4 & 85.8 & 143 & 153 \\
\hline Significance & \multicolumn{2}{|c|}{ NS } & \multicolumn{2}{|c|}{ NS } & \multicolumn{2}{|c|}{ NS } & \multicolumn{2}{|c|}{ NS } & \multicolumn{2}{|c|}{ NS } \\
\hline Moisture content (\%) & & & & & & & & & & \\
\hline 25 & 22.4 & 18.9 & 15.2 & 7.2 & 78.3 & 79.1 & 93.5 & 86.2 & 140 & 154 \\
\hline 125 & 21.8 & 18.8 & 18.3 & 9.1 & 75.1 & 77.3 & 93.4 & 86.4 & 139 & 149 \\
\hline 250 & 15.9 & 13.4 & 24.1 & 10.2 & 68.5 & 76.7 & 92.6 & 86.9 & 150 & 163 \\
\hline Significance & \multicolumn{2}{|c|}{ NS } & \multicolumn{2}{|c|}{$* 10.2$} & \multicolumn{2}{|c|}{$*$} & \multicolumn{2}{|c|}{ NS } & \multicolumn{2}{|c|}{ NS } \\
\hline \multicolumn{11}{|l|}{ Compacion $\left(\mathrm{g} \cdot \mathrm{cm}^{-2}\right)$} \\
\hline 0 (control) & 33.3 & 29.7 & 19.5 & 9.4 & 74.5 & 76.9 & 93.9 & 86.4 & 114 & 125 \\
\hline 20 & 15.8 & 12.7 & 20.4 & 9.0 & 73.1 & 77.6 & 93.5 & 86.6 & 151 & 162 \\
\hline 50 & 11.0 & 8.7 & 17.7 & 8.1 & 74.4 & 78.5 & 92.1 & 86.6 & 164 & 179 \\
\hline \multicolumn{11}{|l|}{ Significance (contrast) } \\
\hline Control vs. compaction & \multirow{2}{*}{\multicolumn{2}{|c|}{$\begin{array}{c}* * * \\
*\end{array}$}} & \multicolumn{2}{|c|}{ NS } & \multicolumn{2}{|c|}{ NS } & \multicolumn{2}{|c|}{ NS } & \multicolumn{2}{|c|}{ *** } \\
\hline $20 \mathrm{~g} \cdot \mathrm{cm}^{-2}$ vs. $50 \mathrm{~g} \cdot \mathrm{cm}^{-2}$ & & & \multicolumn{2}{|c|}{ NS } & \multicolumn{2}{|c|}{ NS } & \multicolumn{2}{|c|}{ NS } & \multicolumn{2}{|c|}{ ** } \\
\hline
\end{tabular}

${ }^{2}$ Results are taken at end of crop.

yShrinkage of peatwool was determined based on the original volume of the filled pot $(1560 \mathrm{ml})$. Drainable pore space and total porosity are expressed on a volumetric basis $(\times 100 \%)$.

NS,*,**,***Nonsignificant or significant at $P=0.05,0.005$, or 0.0005 , respectively. No interaction between irrigation and the preplant treatments.

then the root system would account for $125 \mathrm{ml}$. Our data indicated that pore space was reduced by $80 \mathrm{ml}$ while the substrate expanded by $45 \mathrm{ml}$, also for a total of $125 \mathrm{ml}$. The finding that total porosity was lower at the end of the crop than at the beginning corresponds well with a study by Fonteno et al. (1981). However, the reason for the decrease in total porosity was not due to shrinkage but to the presence and growth of roots.

\section{Nutritional aspects}

Although the nutrient solution concentration and the irrigation frequency were the same for both irrigation systems $(\mathrm{EC}=1.4$ $\mathrm{mS} \cdot \mathrm{cm}^{-1}$ ), the nutrients (cq. electrical conductivity) increased quicker in the Chapin-irrigated pots (Table 4). This quicker build-up of nutrients is probably due to absorption of more nutrient solution when applied from the top. Subirrigated pots will 
Table 4. Total soluble salts (EC) and acidity $(\mathrm{pH})$ of potted chrysanthemums grown in peatwool at 4 weeks after the start of short days (early) and at flowering (late) using the pour-through method.

\begin{tabular}{|c|c|c|c|c|}
\hline & \multicolumn{2}{|c|}{$\mathrm{EC}\left(\mathrm{mS} \cdot \mathrm{cm}^{-1}\right)$} & \multicolumn{2}{|c|}{$\mathrm{pH}^{\mathrm{z}}$} \\
\hline & Early & Late & Early & Late \\
\hline \multicolumn{5}{|l|}{ Irrigation } \\
\hline Ebb and flow & 1.2 & 4.2 & 5.1 & 4.7 \\
\hline Chapin & 1.5 & 1.5 & 5.0 & 4.8 \\
\hline Significance & $* *$ & $* * *$ & NS & NS \\
\hline \multicolumn{5}{|c|}{ Compaction $\left(\mathrm{g} \cdot \mathrm{cm}^{-2}\right)$} \\
\hline 0 (control) & 1.3 & 2.4 & 5.0 & 4.8 \\
\hline 20 & 1.3 & 3.0 & 5.0 & 4.7 \\
\hline 50 & 1.3 & 3.1 & 5.0 & 4.7 \\
\hline Significance & NS & $*$ & NS & NS \\
\hline
\end{tabular}

2Data for irrigation are averages of 36 pots, and for compaction of 24 pots.

NS,*,**,***Nonsignificant or significant at $P=0.05,0.005$, or 0.0005 , respectively.

Table 5. Foliar analyses of potted chrysanthemum at flowering irrigated with subirrigation (ebb and flow) or high-volume drip irrigation (Chapin).

\begin{tabular}{|c|c|c|c|c|c|c|c|}
\hline \multirow[b]{2}{*}{ Irrigation } & $\mathrm{N}$ & $\mathrm{K}$ & $\mathrm{Ca}$ & $\mathrm{Mg}$ & $\mathrm{Mn}$ & $\mathrm{Zn}$ & $\mathrm{Fe}$ \\
\hline & \multicolumn{4}{|c|}{ (\% dry wt) } & \multicolumn{3}{|c|}{$\left(\mu \mathrm{g} \cdot \mathrm{g}^{-1}\right.$ dry wt $)$} \\
\hline Ebb and flow & 4.9 & 7.0 & 1.7 & 0.67 & 225 & 135 & 127 \\
\hline Chapin & 4.6 & 8.4 & 2.2 & 0.39 & 440 & 70 & 276 \\
\hline Significance & $*$ & $* * *$ & $* * *$ & $* * *$ & $* * *$ & NS & $* * *$ \\
\hline $\begin{array}{l}\text { Recommended } \\
\text { range }^{z}\end{array}$ & $4.5-5.0$ & $3-5$ & $1-2$ & $0.5-1.0$ & $30-100$ & $30-100$ & $100-140$ \\
\hline
\end{tabular}

${ }^{z}$ Ontario Ministry of Agriculture and Food tissue analysis guidelines. NS, $, * *, * * *$ Nonsignificant or significant at $P=0.05,0.005$, or 0.0005 , respectively. Degrees of freedom for residual error $=11$.

absorb, at most, the equivalent combined volume of moisture transpired from the leaves and evaporated from the substrate surface. During the initial stages of plant growth after pinching, the evapotranspiration and absorption rates are small with subirrigation due to the limited number of transpiring leaves. With top irrigation, the fertigation solution will penetrate the growing substrate and replace the initially low nutrient charge in the substrate (initial EC $\approx 0.8 \mathrm{mS} \cdot \mathrm{cm}^{-1}$ and $\mathrm{pH}=5.6$ ). The increased nutrient levels in the Chapin-watered pots may be the reason why plants in these pots were larger at the early measurements. At flowering, the EC was significantly higher with the ebb-and-flow irrigation than with the Chapin system. The nutrient levels in the Chapin system remained the same from the early measurements to those at flowering. The EC in planted pots was higher $(+0.6 \mathrm{mS} \cdot \mathrm{cm} 1)$ at the end of the experiment than in pots without plants (data not shown) only for ebb and flow.

Compaction of the substrate increased the salt content at the time of flowering, probably due to the increased amount of substrate, resulting in increased absorption capacity per pot (Joiner and Conover, 1965). The $\mathrm{pH}$ of the growing medium was not significantly affected by irrigation or level of compaction but decreased during the growing period with both irrigation systems. The $\mathrm{pH}$ in pots without plants (data not shown) was 0.7 units higher than in pots with plants at flowering.

Both planting dates (Table 1) produced very large and healthy plants (55. 1 and $50.1 \mathrm{~g}$ dry weight/pot, respectively) with no foliar nutrient deficiency or toxicity symptoms. Foliar analyses showed significantly higher concentration of $\mathrm{K}, \mathrm{Ca}, \mathrm{Mn}$, and $\mathrm{Fe}$ and lower $\mathrm{N}$ and $\mathrm{Mg}$ (Table 5) in plants grown with the Chapin system compared to those with subirrigation. Leaf $\mathrm{K}$ was excessively high, with both irrigation systems resulting in depressed Mg levels with the Chapin system.

These results, in combination with increased plant weights (Table 2) and the lower salt levels in the growing substrate (Table 4), indicated that the root system of Chapin-watered plants was more efficient in absorbing nutrients. Visual inspection indicated that roots and root hairs from Chapin-watered plants were also at the surface of the peatwool while absent at the surface with subirrigated plants throughout the experiment. A more complete air exchange with Chapin-watered pots may have stimulated more root growth and nutrient uptake.

\section{Summary}

PeatWool showed excessive shrinkage $(>30 \%)$ when not compacted at pot filling. Shrinkage took place during the first overhead watering only and did not continue during subsequent irrigations with either irrigation system. Compaction reduced peatwool shrinkage and resulted in larger plants with more flowers. As no other physical factors (drainable pore space, container capacity, and total porosity) were affected, it appeared that the volume of the growing substrate had a positive effect on the growth and flowering of the plants. Although compaction of peatwool required $30 \%$ more medium, a similar type of compaction could easily be accomplished on a potting machine, and could be commercially beneficial. Higher moisture content of peatwool at pot-filling increased drainable pore space and reduced container capacity but did not affect plant growth.

High-volume Chapin-watered plants produced larger plants (by weight) with different foliar nutrient concentrations at flowering than the ebb-and-flow-irrigated plants. Quicker build-up of the nutrient levels in the substrate during the early stages of the crop development and a more complete exchange of air with the Chapin system may have altered root development/activity. Studies are needed to determine the importance of the nutrient and air exchange conditions in the medium for plant development.

\section{Literature Cited}

Blom, T.J. and B.D. Piott. 1989. Reabsorption of growing substrate by subirrigation. Greenhouse Can. 9(3):20, 21.

Blom, T.J. and B.D. Piott. 1990. Comparison of low volume drip and subirrigation systems. HortScience 25:1113. (Abstr.)

Fonteno, W. C., D.K. Cassel, and R.A. Larson. 1981. Physical properties of three container media and their effect on poinsettia growth. J. Amer. Soc. Hort. Sci. 106:736-741.

Fonteno, W.C. and P.V. Nelson. 1990. Physical properties of and plant responses to rockwool-amended substrate. J. Amer. Soc. Hort. Sci. 115:375-381.

Joiner, J.H. and C.A. Conover. 1965. Characteristics affecting desirability of various substrate components for production of containergrown plants. Soil Crop Sci. Sot. Flor. 25:320-328.

Lee, C. W., K.L. Goldsberry, and J.J. Hanan. 1987. Evaluation of loose rockwool as a growing medium for pot chrysanthemums: Comparison with peatlite and soil mixes. Colorado Greenhouse Assn. Bul. 439:2-3.

Milks, R. R., W.C. Fonteno, and R.A. Larson. 1989a. Hydrology of horticultural substrates: II. Predicting physical properties of substrate in containers. J. Amer. Soc. Hort. Sci. 114:53-56.

Milks, R. R., W.C. Fonteno, and R.A. Larson. 1989b. Hydrology of horticultural substrates: III. Predicting air and water content of limited volume plug cells. J. Amer. Soc. Hort. Sci. 114:57+51.

Yeager, T. H., R.D. Wright, and S.J. Donohue. 1983. Comparison of pour-through and saturated pine bark extract $\mathrm{N}, \mathrm{P}, \mathrm{K}$, and $\mathrm{pH}$ levels. J. Amer. Soc. Hort. Sci. 108:1 12-114.

Wright, R.D. 1986. The pour-through nutrient extraction procedure. HortScience 21:227-229. 